\title{
Uncovering the Strategic: The appeal to nature in early twentieth- century architectural discourse in Australia
}

\section{Paul Hogben}

Reference to nature as a source for architectural inspiration has been an enthusiasm for many architectural theorists and practitioners in Australia. Interpretations of this relationship, and its various incarnations and renewals, have been germane to a certain discursive construction of what characterises Australian architecture and the Australian architect. The most fulsome example of this is presented in Leaves of Iron: Glenn Murcutt, Pioneer of an Australian Architectural Form, in which Philip Drew insists on an integral relationship between Murcutt's buildings and the architect's love of nature. Drew states that one of Murcutt's demands is that architecture, while maintaining its man-made identity, should "approach nature, that it possess a comparable richness, variability, and overall continuity" (1985: 45). Murcutt's attachment to nature is depicted as Thoreaulike, inspired by the idea of attaining higher understanding, rationality and truth through an immersion in the "genius loci" of a place and the natural elements of Australian landscapes. This attachment, Drew explains, was fostered at an early age and through a studied fascination with nature and the practical and poetic potential it held for the creation of architecture.

Drew differentiates Murcutt's position from the enthusiasms of a group of Sydney architects whose "escape into nature" in the 1950s and 1960s, he states, was motivated by "a rejection of industrialism and Modern architecture as a symbol of the industrial order" (1985: 21). Unlike Murcutt, with his interests in steel technology, the Miesian floating pavilion and abstraction, these architects favoured rustication, exposed rough-sawn timber and clinker bricks as ways of relating to and representing nature in their buildings. For Jennifer Taylor, the "fresh vision" and poetic response of these "romantic" architects had historical precedents in the Heidelberg school of painters of the 1880s and the landscape movement in eighteenth-century England (1986: 50).

In Drew's and Taylor's accounts, nature is treated as something that touches their subjects through empirical observation, bodily sensations and the imagination. We are given the impression that this encounter is mostly an intimate or meditative affair that prompts a philosophical and practical ethic of architectural decision-making relating to material choices and treatments, relationships with site and surrounds, proportions and architectonic expression. Attributed with Thoreau-like associations and qualities, these Australian encounters are generally not considered part of a formal discourse and carry the suggestion of being the antithesis of institutionalised knowledge. Said to be based on a sympathetic connection with nature and the embrace of its rawness and difficulty, these experiences are presented as being unaffected by the conventional demands and manners of professional and institutionalised discourse. But can they be so disassociated? What are the conditions of 'the said' in describing these experiences? Are these conditions negligible? When turning to primary sources, we find that there are verbal and written formulations involved, in which thoughts and ideas 
are communicated, and there are particular sites from which these formulations have been spoken, written, heard, read and reproduced, all suggesting the existence of discourse. In recognising this existence, it becomes possible to consider frameworks of analysis that uncover dimensions to statements about architecture and nature in Australia that have been obscured by the dominant tendency to sanctify the mytho-poetic idea and encounter.

Moving away from a method that saw discourse as having its own autonomous life, with system-like rules of formation, to a genealogical pursuit of the workings of power that act to objectify and discipline the human body, Michel Foucault gave discourse a special status in the history of the human sciences. In an interview in 1977, Foucault described his focus as the "problem of the 'discursive régime', of the effects of power peculiar to the play of statements" (Foucault 1980: 113). In his work, discourse is treated as a site and instrument of power as strategic action, where the effects of power are attributed to "dispositions, manoeuvres, tactics, techniques, functionings" and that "one should decipher in it a network of relations, constantly in tension, in activity" (Foucault 1977: 26). When there was talk of meaning and value, virtue and goodness, Foucault would look for the play of wills and for strategies of domination (Dreyfus \& Rabinow 1982: 109).

This essay argues that there are dimensions to statements about architecture and nature that reveal the play of wills and strategies for attaining control and authority over the space in which design practices and associated subjects get ascribed with meaning and legitimacy. This 'space' is defined by discourse, as supported by the media, in which ideological, institutional and commercial interests are active. The essay shows that discourse on architecture and nature has had the strategic function of setting up terms for the critical assessment of domestic architecture in Australia. These terms are formed within arguments about the virtues of nature as an inspirational source for architectural design and decoration. The evocation of the primitive and original forms of expression has been used to provide these terms with historical credence. Having the institutional and media resources to foster this discourse meant that certain powers of legitimisation could be created and used for the purposes of making aesthetic and ethical judgements and distinctions. When considering the strategic functions of this discourse, it is the powers of legitimisation that come to the fore.

The focus of this study is the post-Federation period of the 1900s, a time when an appeal to nature was a central tenet of architectural discourse in Sydney. Ideas about using nature as a source of artistic and architectural inspiration were fused with sentiments about national character in architecture and architectural decoration. The first section of this essay describes the thrust of this discourse as it was published in Art and Architecture, the journal of the Institute of Architects of New South Wales. The second section examines an extension of this discourse in the attention that was given to images of South Pacific islands and islander building. These were the first images of the South Pacific islands to be published in the Institute's journal and were editorially valued as potent projections of artistic inspiration coming from a close study of, and sympathetic connection to nature. The final section of the essay examines the strategic functions of this discourse which, as indicated above, centred on establishing critical authority over domestic architecture in Australia. 

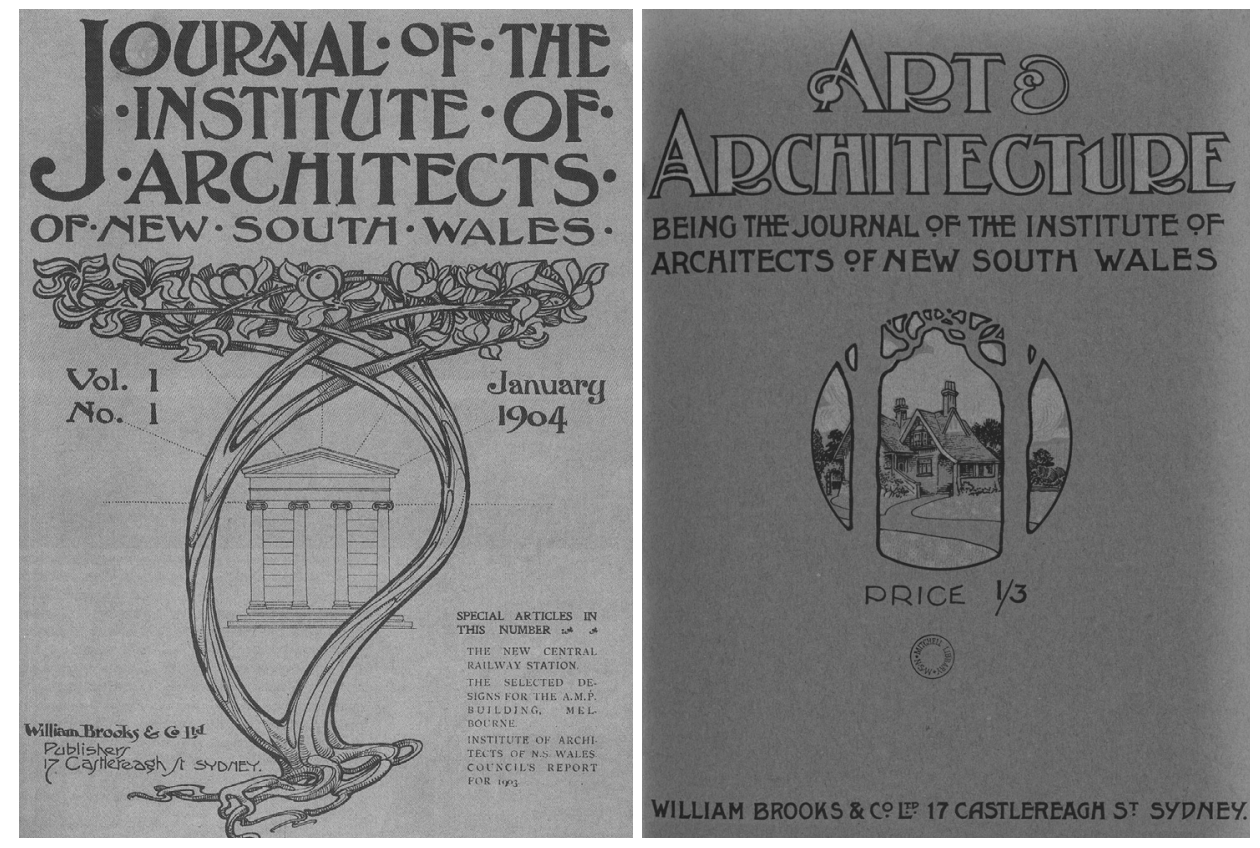

The appeal to Nature

The Institute of Architects of New South Wales was founded in 1871 and in subsequent decades it underwent decline, revival and decline, even to the point where disbandment was contemplated in 1897. Over this time the Institute endured a wavering association with the Sydney building press as a medium for its publicity, an association that often broke down on occasion in outright hostility. ${ }^{1}$ Following the lead of its Victorian counterpart, the Institute initiated a journal of its own in 1904 with the hope that "it may appeal to all who care for Architecture, and not merely to those who follow it as a profession" (Prefatory Note, 1904). The first cover design shows two tree trunks that bow and then intertwine to form a wreath of leaves and floral decoration that couches the name of the journal (Fig. 1). The tree frames an Ionic temple front, an image Philip Goad suggests was meant to reinforce the natural basis of architecture and which echoes the fin-desiècle ideals of William Lethaby (Goad 2004: 19). Indeed, Lethaby is present on the pages of the journal, in an occasional citation, but more so as part of a general set of Ruskinian themes that held sway. In 1905 the title of the journal became Art and Architecture, a name felt more expressive of the ambitions of the editors ${ }^{2}$ and Institute supporters to claim an artistic platform for the architectural profession and to manufacture an image of synchronicity between architecture, art and artistic craftsmanship (Fig. 2). This had been modestly available to Institute members in their previous involvement with the building press and the establishment of their own journal, under the banner of Art and Architecture, breathed new life into architectural discourse in Sydney, with the editorial aim of raising it to a class of literary excellence. The new cover design shows two tree trunks acting as a frame, this time for a rendering of an Arts and Crafts style house nestled in a picturesque landscape, testimony to the rising status of domestic architecture as a focus of discussion. J. M. Freeland stated that the new journal was heavily biased towards the first word of its name and that it was a "luxurious, lavish, art-paper publication full of dilettante articles" (Freeland 1971: 76).
Fig. 1: Journal Cover. Journal of the Institute of Architects of New South Wales, 1(1), (1904).

Fig. 2: Journal Cover. Art and Architecture, 2(2), (1905).
I. The Institute of Architects of New South Wales had entered into arrangements with the Australasian Builder and Contractors' News and the Building and Engineering Journal for access to Institute meetings and the publication of Institute announcements and reports. These journals also published the work and writings of Institute members. What seemed to be mutual good will was broken in 1891 when hostility broke out between John Horbury Hunt, then President of the Institute and the journal editors over allegations of misrepresentation.

2. I use the plural term 'editors' here to refer to the people who edited the Journal of the Institute of Architects of New South Wales (1904) and Art and Architecture (1905-1912) at different times. John Barlow was editor from 1904 to 1908 . George Sydney Jones and David Henry Souter were joint editors from October 1908 to January 1912. Souter was the journal's art editor under Barlow. Nicholas Shiels took over from Jones for the last two issues of Art and Architecture in 1912. 
Freeland's judgement of dilettantism should not belittle the zeal with which the journal's editors and some of it key contributors articulated an argument about the true source of artistic and architectural creativity. They argued that art was not to be based on classical mimesis but on the interpretation of the "spirit" of the Australian landscape: its tone, atmosphere and "dreamy wistfulness", as George Sydney Jones put it (1908: 167). As good landscape artists attempted to capture this spirit in their paintings, architects could represent it in the decorative details and ornaments of their buildings. They believed the impulse towards representing natural beauty in decorative form could be traced back to the earliest acts of primitive man in which lay the seeds of social organisation and the germination of national identity. In an article entitled "A Plea for National Character in Architectural Decoration", George Taylor wrote,

The desire for decoration has always been a characteristic trait of human nature, and the world's most precious historical records are the examples of decoration of ancient peoples. It is doubtful if primitive man would have ever progressed if he had not struggled to make things beautiful, for the appreciation of beauty is not to satisfy the eye alone; the ear and other senses must also participate in the delight; hence pleasant sounds and motions naturally followed. Such expressions being social, to enjoy them there had to be leisure for individuals-hence intercourse between families and so development into tribes and nations. From records preserved we find mankind ever went to Nature for inspiration in design; so primitive man decorated his habitation by picturing the animals of the chase. We find throughout history the style of decoration correlative with the methods of life of the time; and nations adopting decoration more and less peculiar to the aims and temperaments of those nationalities. (1904: 29)

Taylor's article was a case for sgraffito, the technique of inscribing patterns into wall surfaces by making cuts into coloured layers of tinted plaster or cement. He argued that sgraffito, which he said had been used by the Romans, provided a permanent form of decoration in the modern home in comparison to the "makebelieve" and "temporary effect" of things such as machine-pressed leather used to resemble "carved wood" or friezes made of pressed paper pulp. New ornamental shapes and patterns could be taken from fern fronds or the curves of waratah petals. "Nature in Australia is replete with new and suggestive detail," Taylor claimed (1904: 31).

John Bede Barlow, editor of Art and Architecture, held the same opinion as Taylor, stating that Australian flora and fauna provided "endless suggestions" for decorative motifs:

Nature furnishes us with an overwhelming series of designs; and we cannot do better than follow her guidance, for in our reproduction of her glories we write in our decoration a language that those who come after us can easily interpret and understand ... We should leave behind us buildings or decorations that are in harmony with the true and the beautiful, for we should work, not only for the present, but for future generations. (The Editor, 1905a: 136)

One of Art and Architecture's most regular and prominent contributors was George Sydney Jones, who repeated the mantra of nature as a source of artistic and decorative inspiration. In an article entitled "The Spirit of Architecture", 
Jones (using the alias A.B.C.) cited M. Caesar [sic] Daly who, "in one of his works", suggested that architects ought to take thought of the "higher studies" in their art, which Jones interprets as "study of the ideas which lie at the back of all good architecture, and of the thoughts which put those ideas into form and feature" (A.B.C. 1908: 133). For Jones, this was best done by commencing with the study of "Nature".

It is surprising how greatly-oftentimes unconsciously-the study of flowers and plant growth, if regularly undertaken, will influence one's senses of form, and assist in some subtle way to make easier the power of design. For the student, it is a good method to take a particular plant or tree, say a gum-tree, for instance, and make studies of its general form and its parts-the stem, the branch, the leaf-and by this means to get to know and feel the growth and life of the tree. So with flowering plants, such as the Epacris and others, which suitably lend their form and colour to decoration. Gradually, if the student have it not already, that sense of fellowship with all Nature will come, which, having once enveloped him, will be with him at all times-the feel of the plant, the nearness of the distant landscape, the attachment to all living things-in a word, he will enjoy communion with Nature; it will be a "joy for ever," and his design of architecture will be assisted in ways before unknown to him. His work will catch the spirit of the landscape, be in harmony with its tone, and, as an architect, he will move at least one step forward. (A.B.C. 1908: 133-134)

This line of discussion was used by Jones in an article on "Art of the Day", in which he argued that there were signs that artists were "striving to interpret the spirit of Australian life and landscape" and from which architects, as artists having to address utilitarian requirements, could take inspiration (1908: 168). It also formed part of one of his grandest speeches delivered to Institute members, a tour de force of Australian architectural theory in the early twentieth century. In this speech, published as "Architecture-A Factor in National Life", Jones quoted from Vernon Lee's essay "Art and Life" (1896), which posited that the beautiful was "in some manner one of the primordial and so to speak, cosmic powers of the world" (1910: 91). He then cited the English translation of Fustel de Coulanges' La City Antique (1864) in making a point about the way ancient people lavished the Temple with all the art they were capable of and this in turn acted as an enlightening influence on them "as they loved to look upon it, and delighted in its beauty" (1910: 92). It was the combination of proportion, the treatment of light and shade, colour and beautiful details that constituted a beautiful building, the "soul of architecture", and produced the "mysterious influence" it had over people (1910: 92). The great ages of the civilised world had upheld this ideal, the French, the "most brilliant of nations in modern times", cherished it, and the Americans were awakening to it in the present (1910: 93). Jones quoted from Ruskin's The Two Paths in asserting that architecture extended the fellowship of man and in doing so formed the national life of countries (1910: 95). For Jones, architects had to forgo their interests in money and business to put the art of their profession first, and this meant following the credo of "Back to Nature": "[h]e who has the eye and the knowledge to appreciate nature-the beauty of line in the growth of a tree-the colour tones in a landscape, the subtle curve of a path for instance, has much to assist him in creating the beautiful which will be lasting" (1910: 97). 


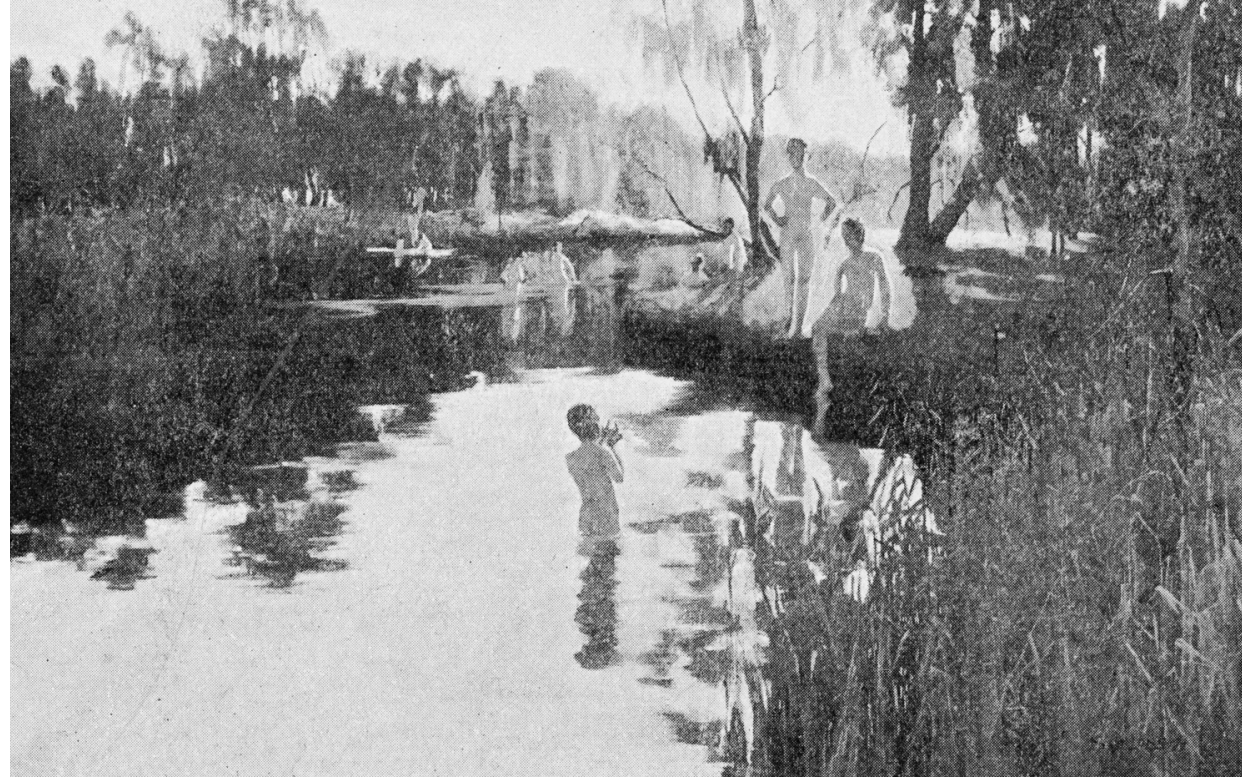

\section{Inflections of the South Pacific}

With the confidence and optimism that followed Australia's Federation in 1901, there was a renewal of interest in imperialist agendas for Australia regarding the Pacific Islands, especially New Guinea and the New Hebrides. These agendas had been formed in the mid-to-late nineteenth century, motivated by colonial commercial enterprises, security concerns and missionary endeavours (Thompson 1980). Australian colonies had to defer to the desires and European complexities of the Colonial and Foreign Offices in Britain in seeking action that would support their interests in the South Pacific. After Federation, Australian imperialist engagement increased, and it was not long before Australia became a colonising power itself, assuming responsibility for British New Guinea in 1906 and pressuring for greater support for its settlers and trading interests in the New Hebrides, in competition with the French. In the light of the Boer War and the Russo-Japanese conflict, Australian groups lobbied for increased influence in decision-making regarding regional matters, including the colonial affairs of Fiji and the Solomon Island. Greater imperialist activity in the South Pacific occasioned growing interest in the islands within the cultural arena. The imperialist quests of the late nineteenth century prompted an influx of art and artefacts into Europe from colonial enterprises in Africa, Australia and the Pacific Islands. This saw the emergence of "primitive art" as an aesthetic category of art criticism and museum collections, and as a source of both avant-garde and commercial artistic interest: "[n]ovelists, poets, painters and musicians, whether in the sphere of high art, that of popular culture, or somewhere in between, also imported the primitive for their own purposes, whether through expropriated images or through the inflections of mediating discourses" (Barkan \& Bush 1995: 10). The editors of Art and Architecture can also be included in this group as they saw in the South Pacific a space of exemplification of the themes they were promoting, publishing three articles on South Pacific buildings and images in the journal.

The first article was entitled "Some Examples of Māori Art", written by Sydney F. Hoben, a music composer who had a familiarity with the anthropological and cultural debates in New Zealand at the time. It is obvious Hoben had read and was reiterating Augustus Hamilton's major study of Māori art that had been published as a collected work in 1901. Hamilton was the first to systematically compile an analysis of "the art workmanship of the Māori" and to recognise its position in the ranks of the decorative arts. Both Hamilton and Hoben held a high admiration for the traditional Māori wood carver and decorator who they claimed possessed skills in "rhythmic accuracy" born from a love of the craft and its significance in their life. Hoben stated:
Fig. 4: Sydney Long, The Bathers, 1894. Art and Architecture, 2(2), (1905): 63. 
Fig. 5: Norman Hardy, On the Fringe of a Primeval Forest. Art and Architecture, 4(5), (1907): 193.

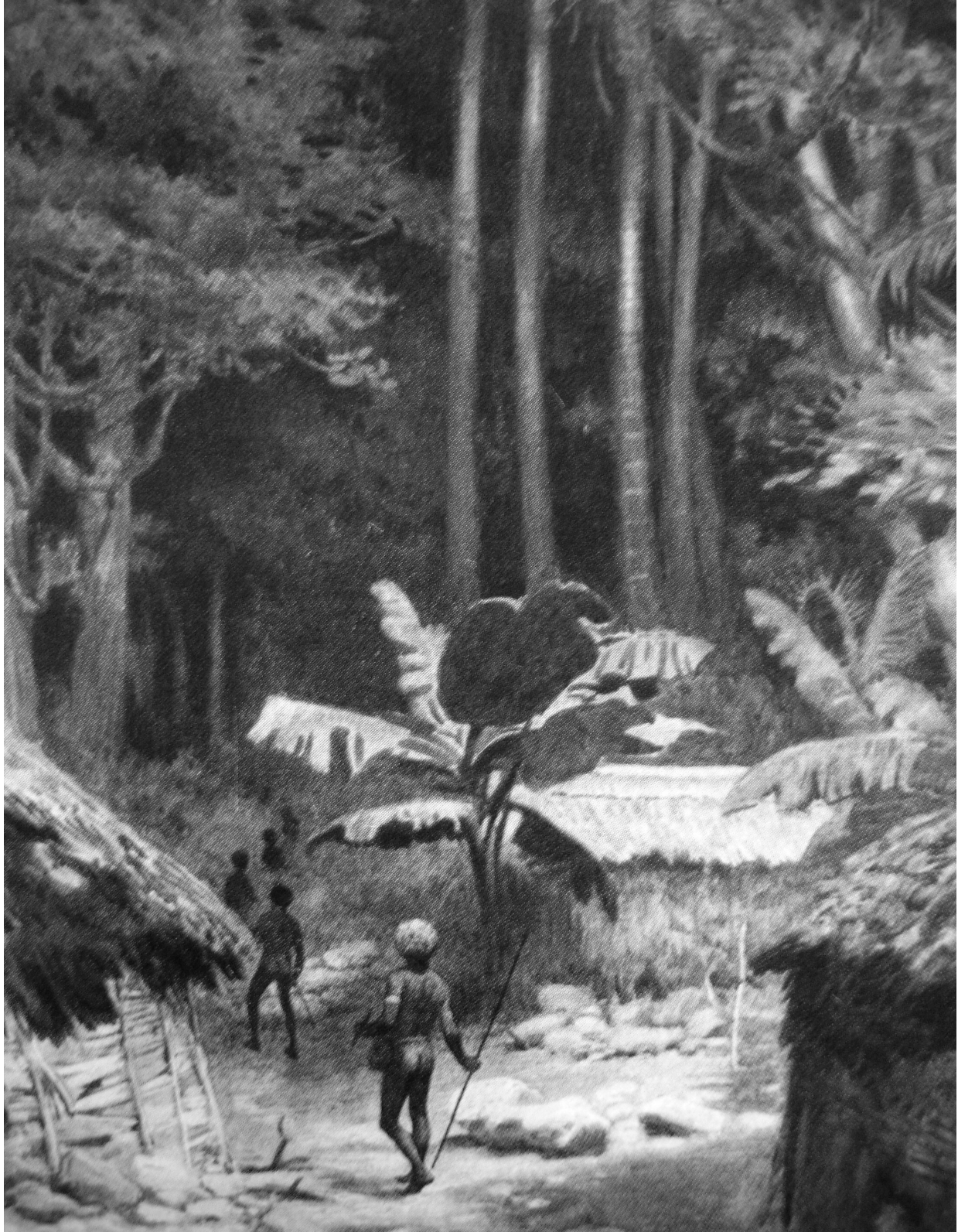

The ancient Māori carved everything he esteemed-his house, canoe, ornaments, domestic utensils, weapons and himself. It was a labour of love, sometimes extending over many years, sometimes over a lifetime. Yet in his special theory of ornament, there was always a sense of the eternal fitness of things. (Hoben 1905: 70)

The carvings of Māori houses had an "artistic quality and force and balance" that Hoben suggested might have sometimes been taken from Greek originals, such as those reproduced in Owen Jones' Grammar of Ornament (Hoben 1905: 71). The "ancient" Māori carver, however, "knew neither Greek or Jones" and their designs rarely represented plant or animal life.

The second article was a book review of The Savage South Seas written by Ernest Way Elkington and published by A. \& C. Black in 1907. The reviewer's interest in the book was two-fold: firstly, because "its subject lies so near our own doors" and, secondly, because the book's illustrations were by Norman Hardy, claimed to be one of Australia's "most enthusiastic and able ethnologists, who devoted his attention solely to the savage races who inhabit our continent and the adjacent seas" (Elkington 1907: 192). Hardy's pictures were praised as "an artistic contribution of facts", one of which was reproduced for the review and called On the Fringe of a Primeval Forest (Fig. 5). This image shows a forest clearing in which stand a cluster of small huts and from which a line of Solomon Islanders trail into the forest. The sublimity of this image is reflected in the commentary about the 


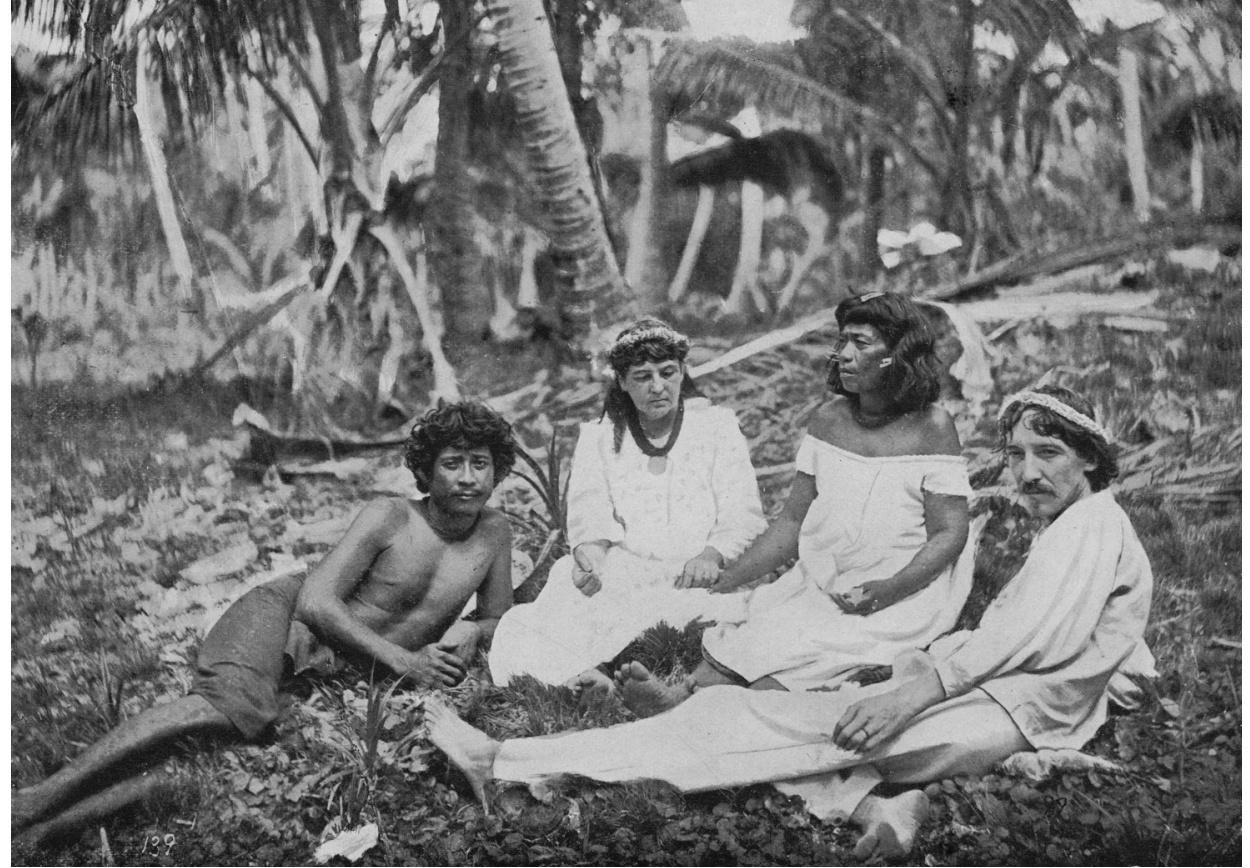

writer's journey into the forest depths in which "long streaks of sunlight were streaming through the tree tops, reminding us of the lights coming though the windows of a cathedral," an echo of the theoretical association that forests have with the origins of Gothic architecture.

The third article to be published in Art and Architecture was entitled "Stevenson in Samoa", containing an image that shows the linen-clad writer reclining on the ground with three others; tropical palm trees provide a background to the scene (Fig. 6). This was a print taken from an original photograph Stevenson had sent to a Sydney photographer along with other negatives from his personal collection, a point that does not escape the interest of Barlow, the article's author, who saw a publishing opportunity to be had. He said that, even though the "Stevenson cult has to some extent of late declined", images of Stevenson's life in the Pacific Islands would still have charm because of the flavour of romance they held in an "unromantic age" - the idea of the artist in fellowship with nature and such "primitive and poetic people as the Samoans" (Barlow 1908: 145). For Barlow, the bond between art, architecture and nature that this represented was seen in the emotional expression and respectful peace that surrounded Stevenson's island home and death chamber.

The editorial selection of these articles, images and books to review demonstrates the value seen in the South Pacific as a space of projection and exemplification of artistic inspiration coming from a close study of, and sympathetic connection to nature and, in the case of the Māori carvers, the "old-age" skill in achieving "decorative agreement" in their houses. Both were prominent themes in writings published in Art and Architecture and these articles and images were utilised editorially as "evidence" of a regional expression of these themes.

\section{Strategic functions}

According to the view being espoused by Art and Architecture, those willing to undertake the study of nature were on the path to discovering the source of truth and beauty in design. Many of the arguments around this view had a didactic quality, setting up the oppositions of honesty and deceit (or sham), the spiritual and the dull, the permanent and the temporary, the free and the confined. This set of oppositions was important for the proponents of this view in that it offered them an entrée into the realm of critical judgement and a framework through which to claim authority in such matters. This was the most strategic aspect of this discourse - to establish and lay claim to the terms of architectural criticism
Fig. 6: Stevenson in Samoa. Art and Architecture, 5(4), (1908): 144. 
5. Of the 46 houses illustrated in the 1905 series on domestic architecture in Sydney, designs by George Sydney Jones and John Barlow featured prominently. Jones had five designs included.

6. Building first appeared in September 1907, published in Sydney and edited by George A. Taylor (not to be confused with the George Taylor mentioned earlier). It claimed to be in the interests of architects, builders, craftsmen and property owners with a focus on the building industry, matters of legal importance, new construction technology and building systems, and although championing its independence from any professional or industry association, it had good connections to the Master Builders' Association of New South Wales (Freestone \& Hanna 2007: 154). and by doing so control the means by which aesthetic and ethical legitimisation could be determined, especially in relation to one of the most lucrative areas of architectural practice in Australia at the time, that of domestic architecture.

The planning of new suburbs and the sub-division of older ones around Sydney in the late nineteenth and early twentieth century created a rich market for modern domestic architecture. Architects were actively positioning themselves to gain commissions in these suburbs, many involving large properties and sizable houses. Art and Architecture offered a valuable site where Institute members could have their house designs presented and discussed and where these members and their clients could look for an indication of current directions. The journal also offered a vehicle through which the legitimacy of particular design practices and decorative trends could be established. In order to initiate this engagement and the potential it held, John Barlow experimented with the publication of two illustrated articles on domestic architecture in New South Wales and Victoria respectively. These articles were followed by a series of four articles on recent domestic architecture in Sydney. Within these articles, aesthetic criteria were used to review selected houses designed by Institute members, employing references to nature and the oppositions described above. In a review of houses in the eastern suburbs of Sydney, it was stated, "Nature could hardly have done more for an architect in the way of providing picturesque sites than she has done on the southern shores of our harbour, but unfortunately her kindness has not always been reciprocated." (Sydney Domestic Architecture 1905: 27) This led an attack on clients who "forced" their architect to "carry out their whims," resulting in "building atrocities" ignorant of aspect and site conditions. The critique of the poor and negligent siting of houses was also an avenue to criticise those architects who were planning buildings to look good on the drawing board, or were copying from foreign magazines, but who were not taking the time to think about the natural features and orientation of a site. In the critique of ornamentation in houses, an area where journal contributors argued nature could be most visibly represented, the commentary centred on notions of decorative restraint and the tendency toward simplicity. This was said to contrast with the ostentation, showiness and "meretricious detail" of houses in which poor client tastes had dictated the outcome.

Mounting a critique of modern domestic architecture in Sydney allowed for the privileging of particular conceptions of architectural practice that were considered ethically and socially responsible. An appreciation of the natural features of a site in the orientation and design of a house and the use of decoration that was restrained and naturally inspired were overarching factors in this. Those practices that showed no interest in these were cast as misguided and irresponsible. Such criteria constituted a grid in which to place and promote the work of Institute members, especially those who were thought to share an affinity with the theories and values of Art and Architecture's editors and main contributors. ${ }^{5}$

There was also another area in which this critical authority carried important legitimising powers. One of the main challenges for the editors of Art and Architecture was to draw in and maintain advertising revenue for the journal. They announced: "[w]e aim at bringing our advertisers in close touch with the class who can afford to pay for more than mere utility and who appreciate the difference between the craftsman and the mechanic" (Jones \& Souter 1908). Appealing to the socio-economic and cultural class of the journal's readers was a way of promoting the advertising value of the journal over its competitors, especially Building. ${ }^{6}$ 

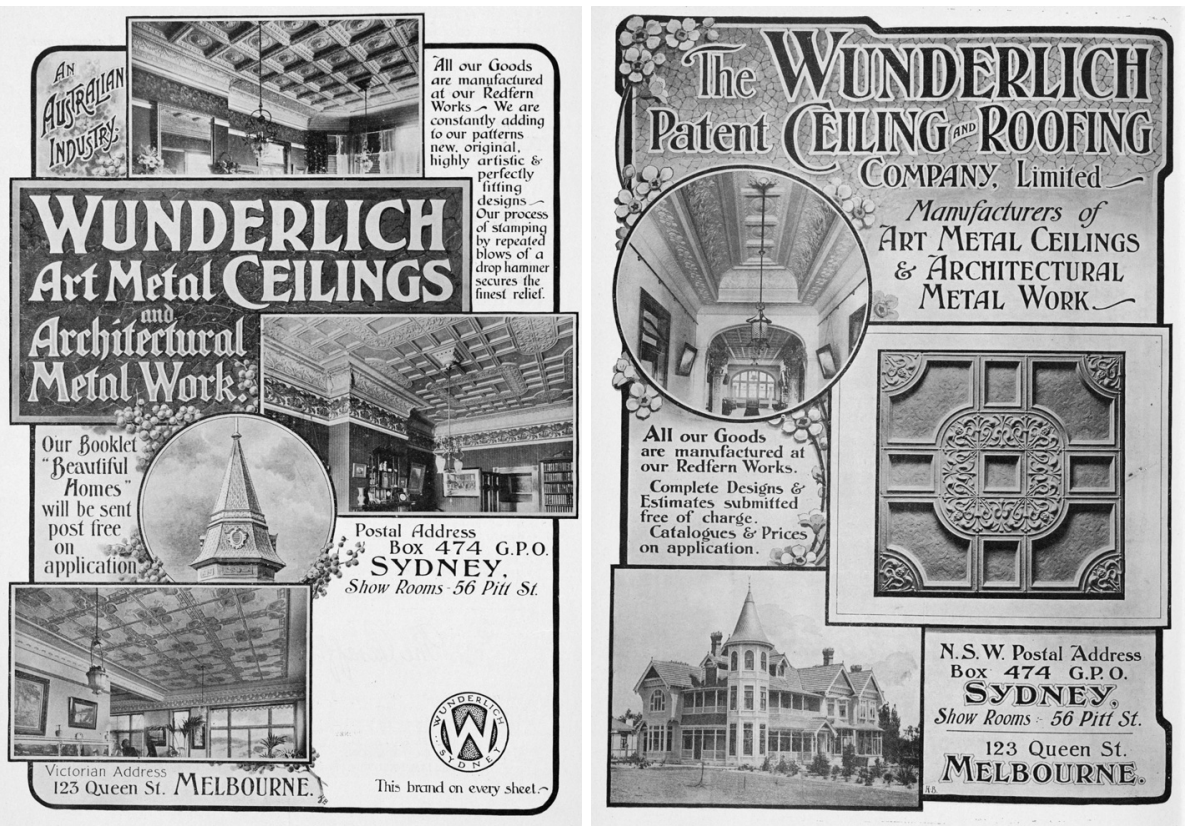

Fig. 7: Advertisement. Art and Architecture, 4(6), (1907): xviii.

Fig. 8: Advertisement. Art and Architecture, 5(5), (1908): xviii.

This was an important audience for those advertisers wanting to increase their presence in the burgeoning marketplace of domestic architecture. Two of these advertisers were the Wunderlich Patent Ceiling and Roofing Company and G.E. Crane \& Sons, both escalating marketing campaigns for their decorative wall and ceiling panels in the 1900s. In 1907 and 1908, advertising by Wunderlich featured images of large suburban houses showing the interior use of its metal ceiling panels embossed with natural patterns and motifs (Figs. 7 \& 8). Several years earlier, Wunderlich had hired Samuel Rowe, a designer trained at the South Kensington School in London, to create modern panel patterns, some of which were based on native flora, including the waratah (Bures 1987: 60).

How could ideas of beauty and truth inspired by a soulful connection with nature be reconciled with the promotion of such mechanically-produced decorative panels? The strategy used to overcome any possible conceptual conflict was to extend the discourse of architecture and nature, with the constructed critical authority it carried, to the aesthetic and ethical legitimisation of particular products and advertiser interests. This is evident in a 1905 article entitled "Stamped Metal-Work", in which Barlow argued that the embossing of metal plates for the decoration of ceilings had ancient origins and, despite the "eloquent invective" of writers such as Ruskin and Morris who argued for a reversion to old methods of production, the "special adaptability of certain materials to certain kinds of workmanship" reduced the loss of artistic individuality and aesthetic value through mechanical repetition and reproduction (The Editor, 1905b: 179). This, Barlow stated, was the case with embossed metal. The distinguishing quality was that of "honesty in intention" and "the absence of any attempt to deceive" in the case of metal panels being made to masquerade as another material. Barlow's article was illustrated with images showing metal ceiling plates made by the Wunderlich Company and G.E. Crane \& Sons, two of Art and Architecture's most prominent advertisers.

The strategic function of drawing in advertisers through the aesthetic and ethical legitimisation of their products served Art and Architecture well. The Wunderlich Company and G.E. Crane \& Sons remained regular advertisers in the journal, 
investing in considerable advertising campaigns. It also meant that the critical authority on domestic architecture that was desired would not run up against the interests of some of the journal's main advertisers, who, in turn, were necessary to financing the publication.

\section{Conclusion}

Following the contours of the discourse on architecture and nature as recorded on the pages of Art and Architecture has revealed the strategic functions of this discourse. They centred on the construction of critical authority over domestic architecture and the powers of legitimisation this could carry: of what was considered truthful and ethically and socially responsible in design practices and of what was artistically and professionally admirable. Ideological, institutional and commercial interests acted within this discourse, energising its production and channelling its powers in certain directions: in this case, towards the work of particular journal contributors, Institute members and journal advertisers.

These findings can be used as a starting point for an analysis of the discourse on architecture and nature in subsequent periods, and the strategic functions that it has held. As with the discourse studied here, the construction of critical authority over domestic architecture was also central to the discursive regime fostered by the publishing interests of Sydney Ure Smith from the mid-1910s onwards, which supported the architectural theories of Leslie Wilkinson, Hardy Wilson and John D. Moore. Unlike the discourse studied here, these theories were based on a romantic conception of architecture and nature that looked to the Mediterranean and the colonial Georgian past for inspiration rather than the wistfulness of local gum trees or the rhythmic decoration of Māori wood carvers.

\section{References}

A.B.C. (1908). The Spirit of Architecture. Art and Architecture, 5(4), 133-134.

Barkan, E. \& Bush, R. (1995). Introduction. In Prehistories of the Future: The Primitivist Project and the Culture of Modernism (pp. 1-19). Stanford: Stanford University Press.

Barlow, J. (1908). Stevenson in Samoa. Art and Architecture, 5(4), 144-146.

Bures, S. (1987). The House of Wunderlich. Kenthurst: Kangaroo Press.

Drew, P. (1985). Leaves of iron : Glenn Murcutt, pioneer of an Australian architectural form. Sydney: Law Book Co.

Dreyfus, H.L. \& Rabinow, P. (1983). Michel Foucault: Beyond Structuralism and Hermeneutics. Second Edition. Chicago: University of Chicago Press.

Elkington, E.W. (1907). The Savage South Seas (Review). Art and Architecture, 4(5), 192-195.

Foucault, M. (1977). Discipline and Punish: The Birth of the Prison. London: Penguin Books.

Foucault, M. (1980). Truth and Power. In C. Gordon (Ed.), Power/Knowledge: Selected Interviews and Other Writings, 1972-1977 (pp. 109-133). New York: Pantheon Books.

Freeland, J.M. (1971). The Making of a Profession: A History of the Growth and Work of the Architectural Institutes in Australia. Sydney: Angus and Robertson.

Freestone, R. \& Hanna, B. (2007). Florence Taylor's Hats: Designing, Building and Editing Sydney. Ultimo: Halstead Press.

Goad, P. (2004). One Hundred Years of Discourse. Architecture Australia, 93(1), 18-26.

Hoben, S. F. (1905). Some Examples of Māori Art. Art and Architecture, 2(2), 70-80.

Jones, G.S. (1908). Art of the Day. Art and Architecture, 5(5), 167-168. 
Jones, G.S. (1910). Architecture: A Factor in National Life. Art and Architecture, 7(4), 91-99. Jones, G.S. \& Souter, D.H. (1908). Letter of Notice. Art and Architecture, 5(5), unpaginated. Long, S. (1905). The Trend of Australian Art Considered and Discussed. Art and Architecture, 2(1), 8-10.

Prefatory Note (1904). Journal of the Institute of Architects of New South Wales, 1(1), unpaginated.

Smith, B. (1979). Place, Taste and Tradition: A Study of Australian Art Since 1788. Melbourne: Oxford University Press.

Souter, D.H. (1905). Sid Long, Landscapist. Art and Architecture, 2(2), 60-66.

Sydney Domestic Architecture: The Eastern Suburbs (1905). Art and Architecture, 2(1), 27-34.

Taylor, G. (1904). A Plea for National Character in Architectural Decoration. Art and Architecture 1(1), 29-32.

Taylor, J. (1986). Australian Architecture Since 1960. North Ryde: The Law Book Company.

The Editor. (1905a). Sgraffito and its Application. Art and Architecture, 2(3), 133-136.

The Editor. (1905b). Stamped Metal-Work. Art and Architecture, 2(4), 175-180.

Thompson, R.C. (1980). Australian Imperialism in the Pacific: The Expansionist Era 1820-1920.

Carlton, Victoria: Melbourne University Press. 